$\underline{3554}$

Session

\title{
A Holistic Approach to Teaching Engineering Entrepreneurship and Technology Commercialization
}

\author{
Carmo D'Cruz, P.N. Vaidy Vaidyanathan \\ University of Central Florida
}

\begin{abstract}
With their creative product and technology ideas, engineers are excellent sources of high growthpotential entrepreneurial and technology commercialization ventures. However, this resource has not been effectively supported by academia in general, to fully realize its potential.

This paper reviews contemporary literature on teaching of entrepreneurship and describes an innovative, holistic inter-disciplinary Engineering Entrepreneurship and Technology Commercialization approach backed by the resources and activities of a technology incubator, to provide engineering students and researchers with tools and opportunities for entrepreneurial success, establish deeper and more meaningful community ties, and facilitate the incubation of investable technology-based start-ups.

Packaging the "incubator concept" into a series of graduate, undergraduate and continuing education short courses is a unique feature of this program, which offers practical insights, tools, objectives, case studies, strategies, mock negotiations and actions that one can apply to any stage of an entrepreneurial or intrapreneurial venture from initial idea to growth and profitability. The ever-pressing issue of funding is presented as a manageable hurdle and options to structure and develop the business to attract potential investors are presented. The critical roles of engineering, marketing, finance and management are clearly explained as the entrepreneur learns practical and leading-edge approaches to bring products to market and grow the organization. Technology commercialization projects, guest lectures and interaction / networking opportunities with successful or struggling technical entrepreneurs, corporate intrapreneurs, angel investors, venture capitalists, corporate technology managers, technology incubator directors, attorneys, financial advisors, consultants, etc are added benefits of this program. Attempts are also made to resolve/avoid IP issues that commonly impact university-industry partnerships. This program has received very favorable reviews from local, state and national organizations.
\end{abstract}

\section{Introduction}

The term "Entrepreneur" is of French origin and was first noted in Savary's 1723 Universal Dictionary of Business as one who undertook a project; was a manufacturer, or a master builder. ${ }^{1}$

Proceedings of the 2003 American Society for Engineering Education Annual Conference \& Exposition Copyright (C) 2003, American Society for Engineering Education 
Adam Smith (1723-1790), who is commonly accepted as the father of free enterprise economics, used the standard terms of the times, that of "projectors and undertakers" to identify entrepreneurial individuals. ${ }^{2}$ Unfortunately, the former term was often given to shady dealers and the latter was subsequently, and for no known reason given over to funeral directors. Smith's undertaker was a "mere capitalist" and while he was important as a decision maker in regard to the division of labor, he was ahead of his time in terms of identifying innovation, the use of capital and the division of labor (but not technology per se) and its dependency on the markets. Jean Baptiste Say (1767 - 1832), who is particularly well known for his "law of markets" and "theory of production" visualized three components of the production process: human industry, capital and national agents. ${ }^{3} \mathrm{He}$ was the first in economic history to identify the value that is contributed to the system by the entrepreneur. Ludwig von Mises (1881-1972) was the first in modern times to come out foursquare in placing the entrepreneurs in the same rank as, if not more important than, the three classical agents of economics - land, capital and labor. ${ }^{4}$

The Austrian economist Joseph Schumpeter (1883 - 1950) believed that the action of entrepreneurs, working their innovations and technology on the market introduces change to what otherwise might be a system at rest or in equilibrium. ${ }^{5}$ Schumpeter saw five possible scenarios that would create a metamorphosis that causes a disequilibrium: 1) introduction of a new product or a new quality, neither of which the consumer is familiar with; 2) application of a new production method or process that relies on innovation, rather than invention; 3) opening up a new market; 4) a new or innovative servicing of material or components and 5) establishing a new organization, either in structure or type. What sets Schumpeter apart from others is that his theory positions the entrepreneur in the role of the prime mover. Others economists who preceded him, Adam Smith, Jean Baptiste Say (1767-1832), and Ludwig von Mises (1881-1972), for example, describe the entrepreneur as a speculator, a co-ordinator or an innovator.

\section{Contemporary Models of Entrepreneurship}

There have been a number of contemporary models of entrepreneurship. In one of the first efforts to explain what makes up an entrepreneur, Blake and Saleh ${ }^{6}$ combine personality factors, knowledge, managerial mechanisms and environmental forces in a schematic that traces out the entrepreneurial process. In this model, the entrepreneur begins a venture by coping with environmental change through three critical responses: 1) uncertainty management 2) knowledge filtering and 3 ) the exploitation of environmental change. What the individual does in this process is helped or hindered by personality characteristics that play a role in guiding the use of mechanisms to perform successfully. The idea is that a person's characteristics will encourage risktaking or networking and co-ordination to bring about a successful launch. This process is initiated by certain occurrences or issues that exist in the environment. An opportunity is seen by the entrepreneur, perhaps as a result of environmental change, who then, through efforts of personality, uses a number of mechanisms such as innovations, or market attraction, to make things happen. In the Entrepreneurial Model propounded by Ford, Churchill and Walker, ${ }^{7}$ there are three classifications that reveal the entrepreneur: These include the historical roots of an individual which are said to be important in bringing him or her to the point of creating the new venture - this Historical Background which includes family, culture physiology, demographics, etc. establishes the values that guide individuals in life and make an important contribution to the

Proceedings of the 2003 American Society for Engineering Education Annual Conference \& Exposition Copyright (C) 2003, American Society for Engineering Education 
entrepreneur. The Personal Elements of the individual (Motivation, Personality, Abilities, Skills) are critical in setting out to understand the entrepreneur and the effect organizational abilities might have on the process. Finally, there is the Outcome, which in fact becomes the process itself: entrepreneurship. In this model, Motivation is the operant condition that initiates the entrepreneurial process. It is the individual desire to build something, to gain recognition or to reach a particular end-state that kick-starts the push to a self-determined future. The new venture creator with a need for recognition and who is confident of his ability to perform will be very motivated. Fred Fry ${ }^{8}$ has suggested that these variables do come together in an equation:

$\mathrm{M}=\mathrm{Ai} \times \mathrm{Ti}$

Where $\mathrm{M}=$ Motivation

$\mathrm{Ai}=$ Antecedent variables (e.g. background, creativity, personality, experience, and education)

$\mathrm{Ti}=$ Triggering factors such as job loss, opportunity, idea, environmental change, etc.)

Fry incorporates a "Triggering event" as a component of motivation. The Antecedent Variables emphasize the roles that historical and personal variables play in defining the entrepreneur.

In examining technically-oriented entrepreneurs, Robert Edwards ${ }^{9}$ lists three primary causes (a) independence, (b) challenge and (c) monetary reasons to be low on the list as being critical to the high tech entrepreneur. Freeser and Dugan ${ }^{10}$ have determined that four factors, distilled from eleven motivational elements, are able to set out the parameters that make up the motivation to become entrepreneurial: (a) feeling of frustration with the employer (b) desire to avoid working for others and be properly rewarded for one's own efforts (c) drive for challenge and advancement (d) intense drive to do one's own thing, to develop one's own ideas.

\section{Teaching of Entrepreneurship}

The field of "Teaching of Entrepreneurship"11 has been divided as to whether entrepreneurship can be taught or not. Those who favor it as an independent academic discipline see it as a distinctive, if not unique component of the free enterprise system. In this respect, it creates wealth, improves the productivity of a region, adds to employment, and offers a more exciting dimension to society. A second consideration is that entrepreneurship contains specific knowledge, concepts and theories that apply in a reasonable and consistent manner across the discipline. The search for an opportunity, the verification or viability of the opportunity and the language of financing are distinct and particular to entrepreneurship in its own right. ${ }^{12}$ Those who do not favor an entrepreneurship discipline are becoming less vocal in their opposition than in the past. Entrepreneurship courses and programs are starting up in business and engineering colleges of esteemed universities. What does remain is the lingering argument that much of what is applied in the process of entrepreneurship includes material that overlaps in other courses. In the early days, a number of large universities claimed that the functions of management - planning, organizing, controlling- are very much evident in entrepreneurship and need not be treated as a uniquely different discipline. The debate did not recognize two critically important features of an entrepreneur: The role of creativity in entrepreneurship, whereby the new concept, invention and innovation that literally takes charge of the entrepreneur. Second, there is the vision that goes along with the new concept. A final argument that the more conservative academics pursued was that, since a new venture cannot really be created in the classroom, the concept of entrepreneurship cannot be taught and that the "concept of starting one's own business" does not require academic treatment. However, teaching entrepreneurship offers the advantage of avoiding those errors and misjudgments made by individuals who ventured before. The academic 
propositions in teaching business to young people also apply in the teaching of entrepreneurship. The number of businesses created and the economic impact of entrepreneurship courses and programs at Stanford, MIT, University of Texas-Austin and other leading universities is testimony to the fact that entrepreneurship skills and know-how can be taught and entrepreneurs can be nurtured through supporting programs in university-based incubators, entrepreneur associations and local business networks. ${ }^{13,14,15}$

\section{Environmental Factors Impacting New Venture Creation}

Given a satisfactory market opportunity, there are a number of environmental elements that must be in place to support a successful start-up. William B. Gartner ${ }^{16}$ lists ten ingredients that are most important to successful venture creation

1) Suitable financing

2) Availability of a competent workforce

3) Accessibility to helpful suppliers

4) Government support, or at least the absence of obstacles

5) Proximity of Universities to assist in research

6) Availability of land or facilities

7) Access to transportation

8) Support of local population

9) Available support services- secretarial, telecommunications, etc.

10) Low entry barriers

Each of the above factors is important, some of them may be more critical to one venture and not another, but all of them have a considerable role in ensuring new venture success. Proximity to universities is noteworthy in two respects: In high tech start-ups where new inventions or technologies play a dominant role, these institutions can make significant contribution to successful start-ups through research, problem solving and engineering support. Another benefit of the university is its business school and the availability of consulting services in terms of marketing, production systems, MIS, accounting and finance advice, etc.

Benjamin Mokry $^{17}$ suggests that in order to create a more receptive environment for entrepreneurship, a number of fundamental societal changes must occur. He supports the major truism that "local communities are the breeding ground of entrepreneurship" and are capable of creating an environment favorable to it. Mokry has added two factors to Gartner's 10 factors that affect entrepreneurial success:

1) Existence of an entrepreneurial sub-culture. The tremendous success of Silicon Valley, Boston, Austin and San Diego very much support the notion that entrepreneurs feed off each other in a synergistic fashion and create their own dynamic environment.

2) Incubator organizations, many of which are initiated by local universities and governments as enterprise centers

Recent studies ${ }^{18}$ have developed a more positive awareness of educating people in entrepreneurship and eventually how to become entrepreneurial. It has been determined that 1) potential entrepreneurs can be encouraged through university-based entrepreneurship programs 2) entrepreneurship within an established definition can be taught and 3) entrepreneurial alumni do 
succeed and they themselves provide further insights and educational materials for dissemination in the classroom. ${ }^{19,20}$

All the above mentioned research findings and other issues and environmental factors were considered when designing the entrepreneurship programs at the university of Central Florida. Additionally, leading entrepreneurship programs in the country were benchmarked and the best practices were adopted. ${ }^{21,22,23}$

\section{Entrepreneurship at University of Central Florida}

The University of Central Florida has been developing a unique interdisciplinary program to promote technical entrepreneurship, facilitate technology transfer and make the Central Florida area a hub of high tech entrepreneurial activity. This program is strongly oriented into steering undergraduate and graduate engineering students towards careers in entrepreneurship.

The University of Central Florida (UCF) is a growing metropolitan research university with comprehensive programs of teaching, research and service to more than 35,000 students. UCF conducts high-tech research in Optics, Lasers, Communications, Simulation, Alternative energy, Materials, and other branches of engineering. UCF has developed, in partnership with industry, world-class centers and institutes that focus on these strengths and other core competencies. UCF's location in the heart of the state's most rapidly growing I-4 technology corridor has led to a unique affinity with the regional businesses and continued supply of students poised to run these businesses. The university has taken a lead role in promoting and developing high-tech growth in Central Florida, having established a very successful technology incubator and strategic alliances with local and state agencies such as the Florida High Tech Corridor Council, Enterprise Florida, etc. UCF is accomplishing its stated mission to be America's leading partnership university through relationships on local, national and international levels. Partnership with the Central Florida Technology Incubator and UCF's Small Business Development Center solidify the university's local connections; promotes technical entrepreneurship and assists UCF researchers in transferring technology to the marketplace.

The Central Florida Technology Incubator is a university-driven community partnership with the mission of building high-tech opportunities into successful business ventures in Central Florida. Its primary goals are to graduate financially stable companies poised for significant revenue growth and to create an effective means for University faculty to commercialize technology through licensing and strategic partnerships. Located adjacent to the UCF campus in East Orlando, the Incubator consists of over 67,000 square feet space with the addition of its new Center for Entrepreneurship in Downtown Orlando.

The local economic downturn in the tourism industry following the $9 / 11$ terrorist attacks has highlighted a strong need to diversify, build a strong technology base and make this region a hub of high tech entrepreneurial activity. The Central Florida region has many of the key components necessary for technology innovation, commercialization and entrepreneurship. These elements include research university systems with steeples of excellence in technology sectors of significant commercial potential such as Photonics, Simulation, Software and Space Sciences. There is also a 
strong commitment from regional policy makers to transform the region's economy heavily rooted in tourism to a diverse, "High Tech, High Fun", community. The need to develop an entrepreneurial culture, facilitate technology transfer and improve upon the current infrastructure for enabling entrepreneurship in the area is imperative. The local universities have excellent programs in entrepreneurship, business and high tech engineering disciplines. The Engineering Entrepreneurship Leadership program in the area aims to produce tech-savvy entrepreneurs who have a comprehensive understanding of the processes of technology development, transfer and commercialization through the establishment of start-up entrepreneurial ventures.

\section{3-Course Engineering Entrepreneurship Program}

The goal of the 3-Course Engineering Entrepreneurship Program is to produce business-savvy engineering entrepreneurs who can leverage their innovative, proprietary university-developed technology and products into creating investable start-ups in the Central Florida area.

This one-year program comprised three courses:

1. Engineering Entrepreneurship

2. High Tech Product Strategy

3. Technology Commercialization Strategies

Completion of a Business Plan is a requirement of the program. This program is oriented towards hands-on entrepreneurial training and focused on business plan development and execution. Students gain valuable insights through the case method and from the networking opportunities and guest lectures by successful and struggling entrepreneurs, business service providers, VCs, Angel investors, attorneys, financial advisors, accountants, and marketers. Engineering Entrepreneurship is an introductory course that outlines the entrepreneurial process and highlights the critical success factors. High Tech Product Strategy focuses on the marketing aspects of entrepreneurship and presents product strategy from a unique, holistic perspective to greatly increase the probability of success. The final course emphasizes project management, other operations strategies necessary to grow the start-up venture and systematically covers the Technical, Marketing and Business aspects of the Technology Commercialization process through the 3 phases (Concept, Development and Commercialization) and six stages (Assessment, Feasibility, Development, Launch, Growth and Maturity).

It has been observed that when engineers are exposed to High Tech Marketing and Product Strategy, their entrepreneurial enthusiasm and instincts take a quantum leap and they develop new paradigms for commercializing their ideas. This zeal, combined with their technical creativity and innovative product ideas creates an "Entrepreneurial Fire in the Belly".

This three-course series is designed to develop a collegial, co-operative learning environment that mimics the activities of a technology incubator. The students pursue their own entrepreneurial ideas and work in teams. These teams are not restricted to the students in the class. They can be virtual teams including external experts as members of the start-up management team or the board of advisors. The enthusiasm in these Engineering Entrepreneurship classes has been observed to be very high - students sometimes arrive an hour before the start of class and often stay over late, huddling and hustling, working in small groups on projects, networking with guest speakers, 
making deals and helping each other out and working on their business plans.

Packaging the "incubator concept" into a series of graduate, undergraduate and continuing education short courses is a unique feature of UCF's overall Entrepreneurship program, which offers practical insights, tools, objectives, case studies, strategies, mock negotiations and actions that one can apply to any stage of an entrepreneurial or intrapreneurial venture from initial idea to growth and profitability. There are some stereo-typical differences between Engineers and Marketers that this holistic Entrepreneurship program attempts to alleviate: Engineers are typically facts oriented, tend to think serially and sequentially with strong paradigms. Marketers on the other hand are typically perceptive and tend to think holistically with flexible paradigms. A successful entrepreneur needs to balance the roles of a engineer, marketer and administrator through different stages of the entrepreneurial venture. The ever-pressing issue of funding is presented as a manageable hurdle and options to structure and develop the business to attract potential investors are presented. The critical roles of engineering, marketing, finance and management are clearly explained as the entrepreneur learns practical and leading-edge approaches to bring products to market and grow the organization. Attempts are also made to resolve/avoid IP issues that commonly impact university-industry partnerships, with guest lectures by the university-affiliated attorneys and technology transfer director.

The academic requirements for these courses are fulfilled through a series of case study assignments in which student teams analyze, write up and lead class discussions on Entrepreneurship and Technology Commercialization - related cases. Additionally, the mid-term assignment involves the development of a comprehensive proposal to raise funds from public and private organizations. In these highly structured and regimented courses, students are also graded on their performance in periodic project reviews, class participation and the comprehensive end-ofterm team project and business plan presentations.

This formal training program is supported and supplemented by other activities and programs of the University of Central Florida Technology Incubator (UCFTI), The College of Business Administration (CBA) and the College of Engineering and Computer Science (CECS) such as:

Excellence in Entrepreneurship Workshop: which is an intense seven-week program that provides entrepreneurs with the business strategies needed to start-up, enhance, grow and strengthen their businesses - culminating in the development of business plans.

Industry Executive for the Day Program: places highly successful industry leaders in the UCFTI for a day for mutually beneficial experiences and interaction between the incubator clients and industry leaders. Under this program, the industry leaders get a closer look at entrepreneurial commercialization efforts of nascent technologies and the incubator clients gain insights from industry veterans.

Entrepreneurship Speaker Series: These seminars by business services professionals, VCs, Business Angels, attorneys, struggling/successful entrepreneurs, etc. are held periodically on topics such as patent protection, legal issues related to high-tech startups, marketing and branding, and raising capital (banks, venture, SBIR, STTR, ATP), etc.

The UCF Engineering Entrepreneurship Colloquiums: are held at the end of the semester with keynote addresses from successful local entrepreneurs, presentation of student business plans and 
panel discussions with industry experts and is a popular networking event.

Bootcamps for Potential Entrepreneurs: These are one-day camps initially developed by the UCF College of Business with customized programs intended to meet the needs of underrepresented groups. These programs include intensive panel discussions focused on answering the questions that challenge most entrepreneurs, incisive insights from successful /struggling entrepreneurs, tips and feedback on business plan preparations, etc. Follow-up Bootcamps for attendees are 2-day or 8-week courses.

UCF Student Entrepreneur Society (UCF SES) is a grassroots students body that promotes entrepreneurship in Central Florida by providing UCF students with a forum to associate with like-minded entrepreneurial students from various disciplines. Through its bi-weekly meetings which feature guest speakers and other activities, UCFSES creates a network of support for current UCF entrepreneurs, and provides guidance, resources and hands-on experience in the entrepreneurial process. Throughout the year, the UCF SES offers seminars given by entrepreneurs who have started businesses from scratch, as well as representatives from organizations which provide advice on how to ensure a start-up business to be successful.

Internship Program for Entrepreneurial Students: The program places students in paid or unpaid internships, working with start up companies in the university-based incubation programs. Networking opportunities facilitated by the UCF Technology Incubator and the UCF Student Entrepreneur Society also help students to identify local companies that match well with their particular business interest or expertise. It is the goal of this program to enrich the academic experience of the student while providing much needed help to the local and incubator client companies.

Competitive Business Idea Pitching Competitions: These competitions held at the end of the semester in conjunction with the UCF Entrepreneurship Colloquiums, have the following objectives: 1) to establish a culture of entrepreneurship 2) create a very visible, well publicized program (in the media, educational system and business community) highlighting the importance of preparing a well thought out, cogent business plan for commercializing innovative ideas, and 3) offer participants the opportunity to bring their ideas to the market place by being mentored and critiqued by active venture capitalists, entrepreneurs, lawyers and others involved in high tech commercialization. The winners were awarded virtual client status in the incubator for six months.

Activities of the Emerging Business Network $(\boldsymbol{E B N})$ : This network, organized and conducted by the UCF Technology Incubator, links together disparate academic, government and industry leaders to improve communications, pool resources, reduce redundancy, and in general foster tech transfer and innovation. It enables exchange of information concerning technology development and provides a clear path to relevant resources of the regional universities and industries. The network also assists in the development of unique collaborations to promote innovation. The monthly "Technology After Dark" forums of EBN are widely attended.

\section{Impact of Entrepreneurship Initiatives at UCF}

Some of the nascent engineering entrepreneurship activities initiated by the UCF Technology Incubator, UCF Office of Research, The College of Engineering and the College of Business Administration have yielded impressive results. The Incubator serves more than 35 companies and has created over 350 jobs in Central Florida since opening its doors in 1999. These affiliate

Proceedings of the 2003 American Society for Engineering Education Annual Conference \& Exposition Copyright (C) 2003, American Society for Engineering Education 
companies have raised over $\$ 60$ million in venture capital and have an average annual salary of $\$ 68,000$. One of these companies, Optium Corp. was among the highest privately VC-funded start-up company in the country in 2001. Rini Technologies, Inc. is a successful high tech startup solely focused on developing innovative thermal management solutions for high power solid state lasers. This technology which was developed as part of a doctoral dissertation has been successfully commercialized by Rini Technologies, Inc. for Defense, Space and Consumer applications.

The high-efficiency Gossammer Wind ceiling fan technology developed by UCF's Florida Solar Energy Center was successfully licensed by the Office of Research into a resounding market winner. This family of energy-efficient fans has achieved a high level of market acceptance and is one of the best selling products in Home Depot since its market introduction.

The second annual Central Florida Technology conference co-sponsored by the University of Central Florida in May 2002 was a highly successful networking event for entrepreneurs, VCs, and local business service providers, attracting over 300 attendees.

The "Bootcamps for Entrepreneurs" an educational outreach program initiated by UCF's College of Business Administration have already graduated over 150 potential entrepreneurs. The "Excellence in Entrepreneurship" program has been held twice a semester and has seen increasing enrollments since its inception.

The Kauffman Foundation awarded the \$50,000 Awareness Grant to UCF to support the Student Entrepreneur Society and the Business Plan Competition at UCF.

\section{Outcomes of the Three Course Program in Engineering Entrepreneurship:}

The three course program in Engineering Entrepreneurship, which takes engineers and trains them to be entrepreneurs, has been adjudged by the National Collegiate Inventors and Innovators Alliance (NCIIA) as "well-planned entrepreneurship course with solid projects and a good sequence," and has been awarded the NCIIA Entrepreneurship Course and Program Development grant of $\$ 15,500$. Entrepreneurial Teams (E-Teams) from this course were awarded E-Team grants totaling $\$ 32,500$ by the NCIIA to commercialize the highly innovative and patented "Zip Vac Bag" and the "Floatation Flood Wall" technologies during the first two terms of the course.

There were 7 students who completed all the three Engineering Entrepreneurship courses in sequence and were awarded the certificates of completion. The student feedback on the course assessment was very positive. This was a unique course sequence that balanced the engineering, marketing and business dimensions of engineering entrepreneurship. They recommended that similar courses on a non-credit basis be initiated for technicians and non-technical personnel in Brevard County. They also recommended more involvement of the NASA Office of Technology Commercialization in these kinds of programs.

There were viable companies that were formed to commercialize the class projects:

1. EnSol, Inc (a subsidiary of Freeform Tech, Inc.) to commercialize the innovative ZIP VAC Bag technology; This company is currently in negotiations with some of the biggest firms in the Zip Loc Bag business to commercialize the technology

2. Plasmonia, Inc. to commercialize the technology to convert natural gas to ammonia, and 
ammonia to ultra-pure $\mathrm{H} 2$ for fuel cells; This company is in the process of applying for the Venture Smart Initiative from the TRDA - Technological Research and Development Authority of the State of Florida.

3. RESI International, Inc. designs, develops and trades in Specialized Medical Exam tables from the Czech Republic.

4. BASE-ics, Inc. is commercializing the innovative Zone Hitter Adjustable Batting Tee product.

5. Star Hunter Corporation - a micro satellite company has been started in Central Florida with an innovative business model.

6. NanoDynamo, Inc. will commercialize UCF's proprietary nanotechnologies.

Additionally, there have been a number of other technology commercialization initiatives that have emanated from the three-course program such as: Floatation Flood Wall (FFW) which is being fabricated in the Rapid Prototyping Lab at UCF; Air-Foil Curved Efficient (ACE) Fan Blades for AC units; Travel Air Filter, Parking Slot Locator, Rotary-Vee Engine Development, etc.

The UCF Engineering Entrepreneurship Colloquiums, which have been held at the end of the past successive semesters as part of the Engineering Entrepreneurship program, have been attracting increasingly larger audiences and have become popular networking events for aspiring engineerturned entrepreneurs, investors and business service providers. The last two colloquiums attracted over 100 attendees each and featured Business Idea Pitching Competitions, high profile panel discussions (on promoting entrepreneurship and technology commercialization in Central Florida and on Raising capital for start-up ventures in tough times, respectively) and experiential key note addresses from successful local technical entrepreneurs.

The written feedback on the quality of presentations at the Business Idea Pitching Competitions from the cross-functional judging committees (comprising VCs, attorneys, entrepreneurs, other investors, executives from local businesses, etc) has been very positive, commending the studententrepreneurs on their innovative technical ideas and realistic business models. Student entrepreneur teams from this program have won accolades and have been selected to present their business plans at national and local competitions and events hosted by organizations such as the NCIIA, C-E-O (Collegiate Entrepreneur Organization) and the Howard J. Leonhardt New Venture Challenge - an International Business Plan Competition in Miami.

The Technological Research and Development Authority (TRDA) of the State of Florida has expressed interest in the proliferation of this kind of "Technical Entrepreneurship" program in community colleges and universities across Florida. Other universities have begun benchmarking / studying the UCF entrepreneurship and incubator program.

\section{Conclusions}

The three-course program in Engineering Entrepreneurship, other Entrepreneurship initiatives and the activities of the UCF Technology Incubator have yielded impressive results thus far. There is a culture of entrepreneurship that has been created on campus and this has resulted in the successful launch of a few high tech start-ups. There is increased awareness of the potential benefits and opportunities from Technology Commercialization. All these successes point to the fact that Entrepreneurship skills can be learned and acquired through a multifaceted Entrepreneurship program. Entrepreneurship programs not only result in start-up companies, they also promote 
intrapreneurial culture and attitudes in established organizations. With their creative product and technology ideas, engineers are excellent sources of high growth-potential entrepreneurial ventures. By creating an environment that fosters entrepreneurship, this resource of engineering entrepreneurial creativity can be tapped to create investable start-ups and have a positive impact on the local economy.

\section{References:}

1. James W. Carland, F. Hoy, W.R. Boulton, and J.C. Carland, et al., "Differentiating Entrepreneurs from Small Business Owners: A Conceptualization," Academy of Management Review, Vol. 9 (2) 1984, pp 354-359

2. Adam Smith, An Inquiry into the Nature and Causes of the Wealth of Nations, Vol 1 (U.K.: Methuen \& Co., 1950), p. 134

3. Kenneth R. Blawatt, Entrepreneurship: Process and Management, Prentice Hall (1998)

4. Robert F. Herbert, and Albert N. Link, The Entrepreneur: Main Stream Views and Radical Critiques, $2^{\text {nd }}$ Edition (New York: Praeger, 1988), p. 127

5. Martin Banks, and Philip Vale, Entrepreneurship and Economic Change (McGraw-Hill, 1990)

6. Clifford G.G. and Shaukry D. Saleh, "A Model of Entrepreneurial Performance," Journal of Small Business Entrepreneurship, 1992 pp 19-26

7. Neil M. Ford, Gilbert A. Churchill and Orville Walker Jr., Sales Force Performance (Lexington Books, D.C. Heath \& Co., 1985)

8. Fred L. Fry, Entrepreneurship: A Planning Approach (NY: West Publishing Co., 1993) p. 40

9. Edward B. Roberts, Entrepreneurs in High Technology: Lessons from MIT and Beyond (New York, Oxford: Oxford University Press, 1991)

10. Henry R. Feeser and Kathleen Watson Dugan, "Entrepreneurial Motivation: A Comparison of High and Low Growth High Tech Founders in Frontiers of Entrepreneurship Research, ed Robert H. Brockhouse, et al.(Wellesley, MA: Babson College, 1989) pp 13-27

11. Allan A. Gibb, "Entrepreneurship, Enterprise and Small Business: State of the Art ?" ed. Bohman and Pousette, Smaforetagsforskning 1 Tiden, $4^{\text {th }}$ Nordic SME Research Conference, Umea Universitet, June 1986

12. John J. Kao, The Entrepreneurial Organization (Englewood Cliffs, N.J.:Prentice Hall, 1991).

13. D. Palmintera, J. Bannon, M. Levin and A. Pagan (2000) Developing High Technology Communities: San Diego. Produced under contract to Office of Advocacy, U.S. Small Business Administration, by Innovation Associates, Inc., Reston, Virginia

14. Pacific Partners Consulting Group (1997). An Economic Impact Study of Stanford University. (1995). Stanford. CA. Pacific Partners Consulting Group. 
15. C. Jansen and D. Jamison (1999). Technology Transfer and Economic Growth. Salt Lake City, Utah: The University of Utah.

16. William B. Gartner, "What Are We Talking About When We Talk About Entrepreneurship ?" Journal of Business Venturing, (5), 1990 pp. 15-28

17. Israel Kirzner, "The Entrepreneurial Process" in The Environment for Entrepreneurship, ed. Calvin A. Kent(Lexington Books, 1984) p. 41

18. Russell M. Knight, "Can Business Schools Produce Entrepreneurs ? An Empirical Study," Journal of Small Business and Entrepreneurship, Vol. 5 (1) Summer 1987

19. AUTM Licensing Survey (1999). http://www.autm.net/surveys99A.pdf

20. D. Schreiberg. The Matchmakers. Stanford Today. (Jan/Feb 1998)

21. J. Aley. The Heart of Silicon Valley: Why Stanford. Fortune. (July 7, 1997) pp 68-69.

22. R. Robison, Technology Transfer. Research Horizons (Summer/Fall 1998). Atlanta: Georgia Institute of Technology

23. L. Tornatzky, Y. Batts, N. McCrea, M. Lewis, and L. Quittman, The Art and Craft of Technology Business Incubation. (1995). Research Triangle Park, N.C. Southern Growth Policies Board.

\section{BIOGRAPHICAL INFORMATION:}

CARMO D'CRUZ served as adjunct faculty in the Industrial Engineering and Management Systems Department (College of Engineering) and the Management Department (College of Business) at UCF. A twenty-year veteran of the electronics and semiconductor industry, Dr. D'Cruz's research and teaching focus is in Engineering Management, Product Strategy, Technology Commercialization, Technical Marketing and Engineering Entrepreneurship. He has a MSEE from Drexel University, a MBA from the University of Texas at Austin and a Doctorate in Engineering Management from Southern Methodist University.

P.N. "VAIDY" VAIDYANATHAN is Assistant VP for Research at the University of Central Florida. His responsibilities include developing inter and multi disciplinary projects across the university by building teams of faculty from various disciplines as required. $\mathrm{He}$ is also active in technology protection and commercialization. His work experience is in both in industry and academia and he has brought products from the laboratory to the market place. His formal education includes degrees in Physics, Mechanical Engineering, Manufacturing Engineering, Business Administration and Materials Science \& Engineering. 


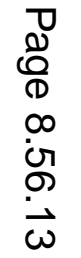

Proceedings of the 2003 American Society for Engineering Education Annual Conference \& Exposition Copyright (C) 2003, American Society for Engineering Education

(S) 